\title{
The Action of Lysozyme on Heat-killed Gram-positive Micro-organisms
}

\author{
BY M. WEBB \\ The Chemistry Department, University of Birmingham
}

SUMMARY: The change in the Gram staining reaction which occurs when heatkilled Gram-positive Clostridium welchii and Staphylococcus albus are incubated with lysozyme is due to the removal of the ribonucleic acid component of the Gram complex, and is brought about by the hydrolysis of certain sugar linkages in polysaccharides located at the cell surface.

Lysozyme, the enzyme in egg-white which lyses living suspensions of susceptible saprophytic micrococci, particularly Micrococcus lysodeikticus, has been the subject of numerous investigations since its discovery by Fleming in 1922. These have been reviewed by Mesrobeanu \& Noeppel (1938) and by Thompson (1940). The enzyme is a basic protein or polypeptide of molecular weight 18,000-25,000 containing about $16 \%$ nitrogen and 2-3\% sulphur (Abraham, 1939; Thompson, 1940). The isolation and purification of lysozyme has recently been improved by a procedure which includes direct adsorption of the enzyme from native egg-white on to bentonite, followed by elution with $5 \%$ aqueous pyridine adjusted to $\mathrm{pH} 5$ with sulphuric acid (Alderton, Ward \& Fevold, 1945).

The first attempt to study the action of lysozyme was made by Meyer, Palmer, Thompson \& Khorazo (1936). Unfortunately, the authors used an enzyme prepared from a Sarcina sp. susceptible to egg-white lysozyme and which had properties similar to the latter enzyme, but which might have contained an autolytic enzyme system of the Sarcina. The enzyme had a specific action on the sugar linkages of certain carbohydrates containing amino sugars, thus supporting an original suggestion of Hallauer (1929). This finding, however, may not apply to lysozyme of egg-white. Epstein \& Chain (1940) isolated a polysaccharide fraction from the cell bodies of $\boldsymbol{M}$. lysodeikticus and other sensitive bacteria which was hydrolysed by lysozyme with production of $\mathbf{N}$-acetyl hexosamine. The polysaccharide was found in all organisms sensitive to lysozyme, the largest amount being present in Bacillus subtilis, an organism which was killed, but not lysed, by lysozyme. Meyer \& Hahnel (1946) confirmed the fact that lysozyme hydrolysed a carbohydrate fraction isolated from sodium hydroxide extracts of the susceptible organisms. Meyer (1946) explained lysozyme action in terms of the hydrolysis of a mucopolysaccharide in the bacterial membrane. This mucopolysaccharide, which appears to be firmly bound to the bacterial membrane, is first depolymerized by lysozyme with consequent water imbibition by the organism and disorganization of the cell. Autolytic enzymes, active after the death of the organisms, were considered to be responsible in part for the clearing of the bacterial suspension. 
It is possible that heat inactivation of the autolytic enzyme systems may be of greater significance in explaining the resistance of killed cells to complete lysis by lysozyme than the fact that cellular proteins are rendered insoluble on heating (cf. Fleming \& Allison, 1922). Lysis of bacteria by lysozyme is preceded by the conversion of the Gram-positive cells to Gram-negative forms (Meyer, 1946); this also occurs when suspensions of heat-killed cells are incubated with lysozyme. Thompson \& Dubos (1938) showed that the first stage of the autolysis of a rough Type II pneumococcus, namely its conversion from Grampositive to Gram-negative without disintegration of cellular structure, was accompanied by the liberation of a ribonucleoprotein and ribonucleic acid. More recently, Henry \& Stacey (1946) have shown that suitable Gram-positive cells can be rendered Gram-negative by extraction with sodium cholate solution at $60^{\circ}$. The bile-salt extract contained inert carbohydrate, traces of protein and lipids, and magnesium ribonucleate. The residual Gram-negative cells, after treatment with suitable reducing agents such as dilute formaldehyde in $0.85 \%$ saline, could be recombined with the magnesium ribonucleate extracted from the same and other micro-organisms, to become Gram-positive again. It was also shown (Henry, Stacey \& Teece, 1945) that a ribonucleoprotein was released during a relatively short autolysis of Clostridium welchii.

Enzymes have been obtained from pancreas (Kunitz, 1940) and from leucocytes (Dubos \& MacLeod, 1938) which convert killed Gram-positive cells to the Gram-negative state; these enzymes have in common the property of hydrolysing ribonucleic acid. Furthermore, one of the autolytic enzymes of Gram-positive micro-organisms which converts the cells to Gram-negative forms also has this property (Jones, Stacey \& Webb, 1948). The results of Spanier \& Deribas (1937), in which it was claimed that egg-white lysozyme contained a nucleotidase active against yeast nucleic acid and which conditioned the bacteriolytic properties of the enzyme, therefore attain a greater significance. These results, which do not appear to have been investigated further, were unfortunately obtained with impure enzyme preparations which hydrolysed with liberation of inorganic phosphate.

In the light of the more recent information concerning the structure of the Gram-positive complex, and of the nature of enzymes capable of affecting the conversion of Gram-positive cells to Gram-negative forms, it was of interest to examine the reactions which occur when such a change is brought about by the action of lysozyme on killed cells.

\section{EXPERIMENTAL}

\section{Preparation of lysozyme}

Lysozyme was isolated from egg-white according to the method of Alderton et al. (1945). Owing to the scarcity of the starting material no attempts were made to crystallize the enzyme. The activity of the preparations, as determined by the method of Goldsworthy \& Florey (1930) against M. lysodeikticus, ranged between 5000 and 6000 lysozyme units/mg. The enzyme solution used contained $1 \mathrm{mg}$. of the lysozyme/ml. 


\section{Action of lysozyme on heat-killed Gram-positive organisms}

Preparation of heat-killed cells. Cultures of Cl. roelchii were grown anaerobically in $2 \%(w / v)$ peptone-glucose broth at $37^{\circ}$. The cells were harvested in a Sharples centrifuge after $18 \mathrm{hr}$. incubation. Streptococcus faecalis and the strains of staphylococci and micrococci were grown on $2 \%$ peptone agar in Roux bottles at $37^{\circ}$ and were removed in distilled water after $24 \mathrm{hr}$. The strains of Staphylococcus aureus used were recently isolated from human pathological specimens; the micrococci were saprophytic organisms isolated from the air and skin.

The centrifuged organisms were washed with distilled water, resuspended in distilled water and killed by heating at $80^{\circ}$. Killed cells, especially those of $\mathrm{Cl}$. welchii prepared by simply immersing a suspension of the Gram-positive bacteria in a waterbath at $80^{\circ}$ for $30 \mathrm{~min}$., were unsuitable since stained smears revealed the presence of a variable percentage of Gram-negative forms. The procedure finally adopted was the 'flash sterilization' method of Dubos \& MacLeod (1938) in which a small volume of bacterial suspension is rapidly added to a large volume of distilled water at $80^{\circ}$. After $30 \mathrm{~min}$. at this temperature the suspension is cooled, centrifuged and the cells resuspended in distilled water.

The fact that Gram-positive cells in aqueous suspension readily pass to the Gram-negative state when heated at $80^{\circ}$ suggests that the components of the Gram-positive complex may be loosely bound. In general, the quantity of lysozyme required to convert heat-killed Gram-positive cells to the Gramnegative state was considerably greater than that required to lyze living suspensions of $\boldsymbol{M}$. lysodeikticus. The method finally adopted was as follows.

A suspension of the killed cells was added to lysozyme solution $(0.5 \mathrm{ml}) .0.2 \mathrm{~m}$ phosphate buffer $\mathrm{pH} \mathrm{7.0}(1.0 \mathrm{ml}$.) and physiological saline $(3.5 \mathrm{ml}$.) so that the final opacity approximated to no. 10 on McFarland's (see Kolmer, 1925) standard barium sulphate scale. The same volume of the cell suspension was added to a control tube containing $0.2 \mathrm{M}$ phosphate buffer $\mathrm{pH} \mathrm{7.0}(1.0 \mathrm{ml}$.) and physiological saline (4.0 ml.). Toluene $(0.1 \mathrm{ml}$.) was used as preservative since it has no effect on the activity of lysozyme (Fleming, 1922). The tubes were corked and incubated at $37^{\circ}$. After appropriate periods, the suspensions were centrifuged and duplicate smears stained by the Gram method; the approximate percentage of Gram-negative cells was estimated visually.

The results (Table 1) show that all the killed Gram-positive organisms, with the exception of yeast, became more or less completely Gram-negative. Suspensions of Strep. faecalis and Staph. aureus (Thompson) were also caused to flocculate. A similar effect, which has been attributed to adsorption of the enzyme by the bacterial cells and to their particular colloidal structure, has been observed with suspensions of living organisms (Friedberger \& Hoder, 1932; Klemparskaya, 1939). The Gram-negative cell bodies remaining after the action of lysozyme were in all cases readily dissolved by trypsin which was without effect on the intact Gram-positive organisms.

Since saprophytic bacteria are, in general, regarded as being more susceptible than pathogenic organisms to lysis by lysozyme (Mesrobeanu \& Noeppel, 1938; Thompson, 1940), it is of interest that the heat-killed cells of the pathogenic strains of Staph. aureus were as susceptible to the action of lysozyme as were the saprophytic micrococci. Furthermore, strains of staphylococci reported to be resistant to the action of lysozyme, i.e. Staph. albus (Epstein \& Chain, 
1940; Thompson \& Khorazo, 1935) and Staph. aureus (Thompson \& Khorazo, 1935), were as susceptible in the killed state to the action of lysozyme as the killed cells of the readily lysed Staph. citreus (Thompson \& Khorazo, 1935).

Table 1. Activity of lysozyme in converting heat-killed Gram-positive cells to Gram-negative forms at $\mathrm{pH} 7 \cdot 0$

\begin{tabular}{|c|c|c|c|c|}
\hline \multirow[b]{2}{*}{ Organism } & & \multicolumn{3}{|c|}{ Approx. $\%$ Gram-negative cells } \\
\hline & $\begin{array}{c}\text { Duration of } \\
\text { exp. (hr.) }\end{array}$ & $\begin{array}{l}\text { Lysozyme- } \\
\text { treated cells }\end{array}$ & & Control \\
\hline Cl. zelchii (S) & 24 & 100 & & 30 \\
\hline Cl. welchii $(\mathbf{R})$ & 24 & $80-100$ & . & 0 \\
\hline Strep. faecalis & 72 & $100 *$ & & 20 \\
\hline Staph. citreus (B9) & 72 & 80 & & 20 \\
\hline Staph. albus (9238) & 24 & 100 & & 20 \\
\hline Staph. aureus (Thompson) $\dagger$ & 72 & $80^{*}$ & & 20 \\
\hline Staph. aureus $482 \dagger$ & 96 & 100 & & 30 \\
\hline $361 \dagger$ & 96 & 100 & & $\mathbf{3 0}$ \\
\hline $709+$ & 96 & $70-80$ & & 30 \\
\hline $395 \dagger$ & 96 & 100 & & $\mathbf{5 0}$ \\
\hline Micrococcius sp. 475 & 96 & $50-60$ & & 10 \\
\hline 446 & 96 & 100 & & 0 \\
\hline 470 & 96 & 100 & & $\mathbf{0}$ \\
\hline 467 & 96 & 70 & & $\mathbf{0}$ \\
\hline Saccharomyces cerevisiae & 72 & 0 & & 0 \\
\hline & 129 & $\mathbf{0}$ & & $\mathbf{0}$ \\
\hline & 168 & $\mathbf{0}$ & & $\mathbf{0}$ \\
\hline
\end{tabular}

The $p H$ optimum for the action of lysozyme on heat-killed Clostridium welchii and Staphylococcus albus

The lysozyme solution ( $0.5 \mathrm{ml}$.) in physiological saline $(3.5 \mathrm{ml}$.) was buffered to various $\mathrm{pH}$ values with $0.2 \mathrm{~m}$ acetate $(\mathrm{pH} \mathrm{2-6})$ or $0.2 \mathrm{~m}$ phosphate $(\mathrm{pH} \mathrm{7-10})$ solutions (1.0 ml.). A uniform, washed suspension of the heat-killed Grampositive organisms (0.5 ml.) was added to each tube of the series. After 48-72 hr. incubation the suspensions were centrifuged and duplicate stained smears prepared. The results (Table 2) show that with each organism the conversion to the Gram-negative state was optimal at $\mathrm{pH} 6$. This value agrees closely with that ( $\mathrm{pH} \mathrm{6 \cdot 2)}$ determined by means of the Moll extinctiometer as the optimum for the lysis of suspensions of $M$. lysodeikticus by the enzyme (Boasson, 1938).

\section{The action of lysozyme on ribonucleic acid}

In view of the claims of Spanier \& Deribas (1937) that lysozyme contains a nucleotidase, and of the fact that enzymes which hydrolyse ribonucleic acid also convert killed cells from Gram-positive to Gram-negative, lysozyme preparations were examined for ribonucleinase activity.

Lysozyme preparations $(0.5 \mathrm{ml}$.) were examined for hydrolytic activity against $0.1 \%(\mathrm{w} / \mathrm{v})$ sodium ribonucleate $(2.0 \mathrm{ml}$.) in $0.2 \mathrm{M}$ acetate buffer pH 6.0 (1.5 ml.) by the method of Davidson \& Waymouth (1944). The unchanged 
ribonucleic acid precipitated by MacFadyen's uranyl acetate-trichloroacetic acid reagent after incubation with the enzyme was centrifuged down after $6 \mathrm{hr}$., washed with $0.125 \%(\mathrm{w} / \mathrm{v})$ uranyl acetate in $1.25 \%(\mathrm{w} / \mathrm{v})$ trichloroacetic acid and analysed for total phosphorus by Allen's (1940) colorimetric method.

Table 2. Variations with $\mathrm{pH}$ in the action of lysozyme on heat-killed Grampositive Clostridium welchii $(S)$ and Staphylococcus albus 9238

Approx. \% Gram-negative cells

$\begin{array}{rcc}\text { pH } & \text { Cl. welchii } & \text { Staph. albus } \\ 2 \cdot 0 & 10 & 30 \\ 3 \cdot 0 & 20 & 30 \\ 4 \cdot 0 & 30 & 50 \\ 5 \cdot 0 & 70 & 100 \\ 6 \cdot 0 & 100 & 100 \\ 7 \cdot 0 & 90-100 & 90-100 \\ 8 \cdot 0 & 90 & 90 \\ 9 \cdot 0 & 90^{*} & 80 \\ 10 \cdot 0 & 50-60^{*} & 60\end{array}$

Duration of experiment $48-72 \mathrm{hr}$.

* Cells gelatinous in character and emulsified with difficulty.

Table 3. Examination of lysozyme for ribonucleinase activity

\begin{tabular}{cccccccc}
$\begin{array}{c}\text { Time of } \\
\text { incubation } \\
\text { at 37 } \\
\text { (hr.) }\end{array}$ & \multicolumn{7}{c}{$\begin{array}{c}\text { Phosphorus content (mg.) of ribonucleic acid precipitated after } \\
\text { incubation with lysozyme preparations }\end{array}$} \\
\cline { 2 - 7 } & B1 & A1 & A2 & A4 & E5 & L4 & L5 \\
1.0 & 0.083 & 0.048 & 0.048 & 0.050 & 0.087 & 0.052 & 0.035 \\
1.5 & - & 0.047 & 0.046 & 0.053 & - & - & - \\
2.0 & 0.083 & - & - & - & 0.086 & - & - \\
3.0 & 0.090 & 0.046 & 0.046 & 0.049 & - & 0.053 & 0.034 \\
3.5 & - & - & - & - & 0.087 & - & - \\
4.5 & - & 0.050 & 0.045 & - & - & - & 0.038 \\
5.0 & 0.082 & - & - & - & 0.085 & - & - \\
6.0 & - & 0.045 & 0.045 & 0.049 & - & 0.049 & - \\
6.5 & 0.084 & - & - & - & - & - & - \\
8.0 & 0.088 & - & - & - & - & 0.051 & 0.035 \\
$\mathbf{2 4 . 0}$ & - & - & - & - & 0.088 & - & -
\end{tabular}

The colours were compared in the Spekker adsorption photometer, using Ilford 608 filters. The results (Table 3) show that lysozyme has no ribonucleinase activity.

Liberation of reducing sugar during the action of lysozyme on heat-killed cells

Although only relatively small increases in reducing sugar were obtained in these determinations, the Schaffer-Hartmann (1920) method of analysis used in conjunction with the recently described starch-glycollate indicator (Peat, Bourne \& Thrower, 1947) gave accurate and reproducible results. Somogyi's (1937) modification proved unsatisfactory, as changes occurred in the standard alkaline copper solution on standing. 
Control experiments showed that no liberation of reducing substances occurred when lysozyme solutions or suspensions of killed cells were incubated alone. When, however, suspensions of killed cells were incubated with lysozyme until Gram-negative, small amounts of reducing sugar were liberated (Table 4) as shown by the following experiments.

Staph. albus. The cells from 20 Roux bottles of a $24 \mathrm{hr}$. culture of the organism $(\bumpeq 2 \cdot 5-3 \mathrm{~g}$. dry cells) were removed in distilled water and killed by the 'flashsterilization' method. The washed cells in distilled water $(50 \mathrm{ml}$.) were added to $0.2 \mathrm{M}$ acetate buffer $\mathrm{pH} 6.0(60 \mathrm{ml}$.) and lysozyme $(45 \mathrm{ml}$.) and the resulting suspension incubated at $37^{\circ}$ in the presence of toluene $(5 \mathrm{ml}$.). At suitable intervals during the change from Gram-positive to Gram-negative samples of the suspension were with-

Table 4. Liberation of reducing sugar during the conversion of heat-killed Gram-positive Staphylococcus albus and Clostridium welchii to Gramnegative forms by lysozyme

Total reducing sugar (mg. as glucose) liberated during the action of lysozyme on heat-killed

$\begin{array}{cccc}\text { Time (hr.) } & \text { Staph. albus } & \text { Staph. albus } & \text { Cl. welchii } \\ 0 & 0.00 & 0.00 & 0.00 \\ 21.5 & - & - & 2.36 \\ 22.0 & \mathbf{0 . 8 4} & - & - \\ 45.0 & -.5 & -35 & - \\ 47.0 & 1.95 & - & - \\ 70.0 & - & - & - \\ 93.0 & \mathbf{3 . 5 7} & - & - \\ 100.0 & - & - & - \\ 126.0 & \mathbf{3 . 9 6} & - & -\end{array}$

drawn and centrifuged at high speed (6000 r.p.m.) until the supernatants were clear and free from cells. The reducing sugar (as glucose) $/ 5 \mathrm{ml}$. (Table 4) in each solution was then determined by the Schaffer-Hartmann method.

$\mathrm{Cl}$. reelchii. The cells from $600 \mathrm{ml}$. of an $18 \mathrm{hr}$. broth culture $(\bumpeq 0 \cdot 3 \mathrm{~g}$. dry cells) were collected (centrifuge), washed with distilled water and killed by the 'flashsterilization' method. A suspension of the cells in distilled water $(30 \mathrm{ml}$.) was added to lysozyme $(5 \mathrm{ml}$.$) in 0.2 \mathrm{M}$ acetate buffer $\mathrm{pH} 6.0(15 \mathrm{ml}$.$) and incubated at 37^{\circ}$ in the presence of toluene $(2 \mathrm{ml}$.). Analyses for reducing sugar, made during the conversion from Gram-positive to Gram-negative as described above, yielded the results recorded in Table 4.

Action of lysozyme on the specific carbohydrates of Staphylococcus citreus (B 9) and Clostridium welchii

The carbohydrates used were crude preparations isolated by procedures which, in the case of the staphylococcus, did not destroy the Gram staining properties of the organism, and, in the case of $\mathrm{Cl}$. welchii did not destroy the cellular structure, although the Gram reaction became negative. The polysaccharides may, therefore, be considered as surface components of the bacterial cells.

The carbohydrate from Staphylococcus citreus $(B 9)$. Of the several methods investigated for the isolation of the polysaccharide, namely extraction with 
$0.05 \mathrm{~N}$ sodium hydroxide at $60^{\circ}, 0.06 \mathrm{~N}$ hydrochloric acid at $100^{\circ}$ for $30 \mathrm{~min}$. (Julianelle \& Wieghard, 1935), $2 \%$ sodium cholate at $60^{\circ}$ and distilled water at $100^{\circ}$ for $5 \mathrm{hr}$., the last was found to give the best results. The procedure was as follows:

The growth from 20 Roux bottles of a $48 \mathrm{hr}$. culture of Staph. citreus $(\bumpeq 2 \cdot 5-3 \mathrm{~g}$. dry cells) was removed in distilled water $(200 \mathrm{ml}$.). The suspension was filtered through glass-wool and then centrifuged. The cells were washed twice with distilled water, suspended in distilled water $\left(100 \mathrm{ml}\right.$.) and heated for $5 \mathrm{hr}$. at $100^{\circ}$, cooled and centrifuged. Acetic acid $(5 \mathrm{~N})$ was added to the supernatant to bring to $\mathrm{pH} 3.5$ and the resulting precipitate removed (filtration) after $2 \mathrm{hr}$. Sodium acetate $(1 \mathrm{~g}$.) was dissolved in the filtrate and the crude polysaccharide precipitated by the addition of ethanol (4, vols.). After 24 hr. the precipitate was collected (centrifuge), suspended in distilled water $(50 \mathrm{ml}$.$) and 50 \%(\mathrm{w} / \mathrm{v})$ trichloroacetic acid $(5 \mathrm{ml}$.) added. The precipitate formed was removed (filtration) after $30 \mathrm{~min}$. and the carbohydrate reprecipitated from the filtrate by the addition of ethanol (4 vols.). After $48 \mathrm{hr}$. the precipitate was collected (centrifuge), dissolved in distilled water $(40 \mathrm{ml}$.) and the above process repeated until no further material was precipitated by the addition of trichloroacetic acid. The solution was then dialysed against tap water $(3 \times 1000 \mathrm{ml}$. $)$ for $48 \mathrm{hr}$. and filtered. Sodium acetate $(1 \mathrm{~g}$.) was dissolved in the filtrate and the polysaccharide then precipitated by the addition of ethanol ( 5 vols.). The precipitate was collected (centrifuge) after $48 \mathrm{hr}$., washed with ethanol and dried with ethanol and ether.

The cells from a total of 120 Roux bottles yielded $400 \mathrm{mg}$. of polysaccharide as a white powder having $[\alpha]_{D}=+16^{\circ}$ in water $(c=1 \cdot 0)$. Aqueous solutions gave a negative biuret reaction and were non-reducing before hydrolysis.

The carbohydrate from Clostridium welchii. The cells from $10 \mathrm{l}$. of an $18 \mathrm{hr}$. culture of $\mathrm{Cl}$. welchii ( $\bumpeq 5 \mathrm{~g}$. dry cells) were washed with distilled water and suspended in $0.05 \mathrm{~N}$ sodium hydroxide $\left(100 \mathrm{ml}\right.$.). The suspension was maintained at $60^{\circ}$ for $18 \mathrm{hr}$. and then centrifuged. Acetic acid ( $5 \mathrm{~N}$ ) was added to the clear supernatant to bring to $\mathrm{pH} \mathrm{3.5}$ and the resulting precipitate removed by filtration after $2 \mathrm{hr}$. The crude polysaccharide precipitated from the filtrate by the addition of ethanol ( 4 vols.) was purified by repeated fractionation with trichloroacetic acid as described above. Finally, the polysaccharide was precipitated with ethanol (5 vols.), washed with ethanol and dried with ethanol and ether.

The cells from 401 . of culture medium yielded $313 \mathrm{mg}$. of the specific polysaccharide as a white powder which showed $[\alpha]_{D}=+51^{\circ}$ in water $(c=0 \cdot 7)$. The carbohydrate was readily soluble in water (concentrated aqueous solutions exhibiting high viscosity) and was precipitated from solution by copper sulphate, uranyl acetate and ferric chloride. It was non-reducing before hydrolysis. With ninhydrin a weak positive reaction was obtained, but no precipitation occurred on adding $50 \%(\mathrm{w} / \mathrm{v})$ trichloroacetic acid to the concentrated aqueous solution.

Aqueous solutions of these polysaccharide fractions adjusted to $\mathrm{pH} 6$ were incubated at $37^{\circ}$ with lysozyme in the presence of toluene. At the time intervals shown in Table 5, $5 \mathrm{ml}$. fractions were withdrawn and analysed for reducing sugar according to the Schaffer-Hartmann method. The results (Table 5) show that both the specific carbohydrate of Staph. citreus and $\mathrm{Cl}$. welchii were hydrolysed to a small but definite extent by lysozyme.

Initially the carbohydrate and lysozyme solutions were completely clear and 
free from particles in suspension, but on incubation of the mixed polysaccharide and enzyme solutions some precipitation occurred within $24 \mathrm{hr}$. This observation may possibly have some bearing on the phenomenon of bacterial flocculation by lysozyme.

It appeared from these results that when lysozyme acts on heat-killed cells a small proportion of reducing sugar is liberated from carbohydrate material located at the surface of the cells. In support of this, it was found that reducing substances were not liberated by the action of lysozyme on $\mathrm{Cl}$. welchii cells which had been rendered Gram-negative by extraction with sodium cholate (Henry \& Stacey, 1946), a process which is known to be accompanied by the loss of ribonucleic acid and carbohydrate from the cell surface.

Table 5. Hydrolysis of the specific carbohydrates of Staphylococcus citreus and Clostridium welchii by lysozyme at $\mathrm{pH} 6$

Mg. reducing sugar (as glucose) liberated/100 mg. polysaccharide from

$\begin{array}{ccccc}\text { Time (hr.) } & \text { Staph. citreus* } & \text { Staph. citreus* } & \text { Cl. welchii* } & \text { Cl. welchii } \dagger \\ 0 & 0 & 0 & 0 & 0 \\ 24 & 1.39 & 1.50 & 1.65 & 0.68 \\ 50 & 1.42 & - & 2.00 & 0.74 \\ 120 & - & 1.59 & - & - \\ 164 & 1.42 & 1.75 & 2 \cdot 17 & 1 \cdot 16\end{array}$

* $60 \mathrm{mg}$. polysaccharide in distilled water $(13 \mathrm{ml}$.) with lysozyme $(2 \mathrm{ml}$. $)$ in $0 \cdot 2 \mathrm{M}$ acetate buffer $\mathrm{pH} 6 \cdot 0(10 \mathrm{ml}$.).

$\dagger 110 \mathrm{mg}$. polysaccharide in distilled water $(12 \mathrm{ml}$.) with lysozyme $(3 \mathrm{ml}$.$) in 0.2 \mathrm{M}$ acetate buffer pH 6.0 (5 ml.).

Since the conversion of Gram-positive cells to Gram-negative forms is known to involve the removal of ribonucleic acid from the cell surface, it appeared from the experimental results thus far obtained that this change must occur concurrently with the hydrolysis of surface carbohydrate substances which takes place when killed cells are rendered Gram-negative by the action of lysozyme. That this is the case is proved by the following experiments in which fractions were isolated from the material liberated by the action of lysozyme on heat-killed Staph. albus and $\mathrm{Cl}$. welchii and which, in each case, had the properties of a ribonucleic acid.

\section{Isolation of ribonucleic acid from the material liberated from heat-killed}

Staphylococcus albus and Clostridium welchii during the lysozymeinduced change from Gram-positive to Gram-negative

Staph. albus. A suspension of heat-killed Gram-positive Staph. albus (9238) cells from 20 Roux bottles $(\bumpeq 2.5-3 \mathrm{~g}$. dry organisms) in distilled water $(50 \mathrm{ml}$.) was incubated with lysozyme $(45 \mathrm{ml}$.) in $0.2 \mathrm{M}$ acetate buffer $\mathrm{pH} 6.0(60 \mathrm{ml}$.) and toluene (5 ml.) until the cells were completely Gram-negative $(170 \mathrm{hr}$.). The suspension was then centrifuged and the crude nucleic acid precipitated from the clear supernatant by the addition of an equal volume of $0.25 \%(\mathrm{w} / \mathrm{v})$ uranyl acetate in $2.5 \%(\mathrm{w} / \mathrm{v})$ trichloroacetic acid solution. The precipitate was collected by centrifuging after standing for $18 \mathrm{hr}$., suspended in distilled water $(20 \mathrm{ml}$.) and $0.5 \mathrm{M}$ sodium carbonate $(2 \mathrm{ml}$.) added. The insoluble material (biuret positive, Molisch negative) was removed at the centrifuge after 5 min., and the clear supernatant brought to $\mathrm{pH} 2.5$ with 
$5 \mathrm{~N}$ acetic acid. After $18 \mathrm{hr}$. the precipitate (biuret negative) was centrifuged down, suspended in distilled water $(15 \mathrm{ml}$.) and $0.5 \mathrm{M}$ sodium carbonate added until complete solution was obtained. Acetic acid (2 N) was then added to $\mathrm{pH} 6.0$ and the solution centrifuged. Lanthanum acetate $(1 \%(\mathrm{w} / \mathrm{v})$; cf. Caspersson, Hammarsten \& Hammarsten, 1935) was then added dropwise to the clear supernatant until no further precipitation occurred. The solid was collected at the centrifuge after $18 \mathrm{hr}$., suspended in distilled water $(15 \mathrm{ml}$.) and dissolved by the dropwise addition of $0.5 \mathrm{M}$ sodium carbonate. Separation of lanthanum carbonate occurred on standing. After $6 \mathrm{hr}$. the suspension was centrifuged and the precipitate washed once with distilled water containing a little sodium carbonate. The combined supernatants were adjusted to $\mathrm{pH} 2.5$ with $\mathrm{N}$ hydrochloric acid and the resulting precipitate collected (centrifuge) after $18 \mathrm{hr}$. The deposit was washed with ethanol and dried with ethanol and ether. Yield $43 \mathrm{mg}$. of a light brown powder.

$C l$. welchii. The cells from $6 \mathrm{l}$. of a $16 \mathrm{hr}$. culture of $\mathrm{Cl}$. welchii $(\Omega 3.0 \mathrm{~g}$. dry cells) were collected (Sharples Supercentrifuge), washed once with water, suspended in distilled water and killed at $80^{\circ}$. A suspension of the cells in distilled water $(70 \mathrm{ml}$.) was incubated at $37^{\circ}$ with lysozyme $(50 \mathrm{ml}$.) in $0.2 \mathrm{M}$ acetate buffer $\mathrm{pH} 6.0(80 \mathrm{ml}$.) and toluene ( $2 \mathrm{ml}$.) until the cells were completely Gram-negative (4-5 days). The suspension was then centrifuged and the clear supernatant $(180 \mathrm{ml}$.) precipitated by the addition of the uranyl acetate + trichloroacetic acid reagent $(180 \mathrm{ml}$.). Purification of the precipitate according to the above method yielded $65 \mathrm{mg}$. of a light brown powder.

The preparations from Staph. albus and $C l$. welchii thus obtained contained a high percentage of ash (Table 6) which was green in colour. The percentage of these inorganic substances (possibly introduced as impurities present in the lanthanum acetate) in the fraction from the staphylococcus could be diminished from 26 to $19 \%$ by dialysis of a solution of the material in dilute sodium carbonate, but could not be removed completely.

\section{Properties of the nucleic acid fraction from Staphylococcus albus and Clostridium welchii}

The analytical figures (corrected for ash) found for the two preparations are recorded in Table 6 and are compared with the theoretical values calculated for ribonucleic acid of the formula $\mathrm{C}_{38} \mathrm{H}_{49} \mathrm{O}_{29} \mathrm{~N}_{15} \mathrm{P}_{4}$.

Table 6. Properties of the nucleic acid fraction from Staphylococcus albus and Clostridium welchii

\begin{tabular}{|c|c|c|c|}
\hline \multirow[b]{2}{*}{ Property } & \multicolumn{2}{|c|}{ Nucleic acid fraction from } & \multirow{2}{*}{$\begin{array}{l}\text { Calc. for ribo- } \\
\text { nucleic acid } \\
\mathbf{C}_{38} \mathbf{H}_{49} \mathbf{O}_{29} \mathbf{N}_{16} \mathbf{P}_{4}\end{array}$} \\
\hline & Staph. albus & Cl. welchii & \\
\hline Biuret reaction & Negative & Negative & - \\
\hline Millon's reaction & Negative & Negative & - \\
\hline Ninhydrin reaction & Negative & Negative & - \\
\hline Feulgen (deoxypentose) reaction & Negative & Weak positive & - \\
\hline Dische reaction & Negative & Weak positive* & - \\
\hline $\operatorname{Ash}(\%)$ & $26 \cdot 0$ & $\mathbf{2 6} \cdot \mathbf{8}$ & - \\
\hline $\mathbf{N}(\%)$ & $15 \cdot 2$ & $14 \cdot 8$ & $16 \cdot 14$ \\
\hline $\mathbf{P}(\%)$ & $\mathbf{9 \cdot 2}$ & $8 \cdot 7$ & $9 \cdot 64$ \\
\hline Ratio $\boldsymbol{N} / \boldsymbol{P}$ & $1 \cdot 65$ & $1 \cdot 7$ & $1 \cdot 69$ \\
\hline Pentose (Bial) (\%) & $54 \cdot 1$ & $43 \cdot 6-46 \cdot 6$ & $46 \cdot 1$ \\
\hline Pentose/phosphorus & 4.9 & $5 \cdot 0-5 \cdot 35$ & $4 \cdot 84$ \\
\hline
\end{tabular}

* Corresponding to the presence of 3-5\% deoxyribonucleic acid. 
Further evidence for the identity of these fractions with ribonucleic acid was provided by the following facts.

The preparations exhibited strong adsorption bands at $260.0 \mathrm{~m} \mu$. which, after correcting for the differences in ash content, corresponded with the adsorption band given by a solution of the same concentration of ribonucleic acid purified as described by Henry \& Stacey. (1946) (ash content $8.7 \%$ ).

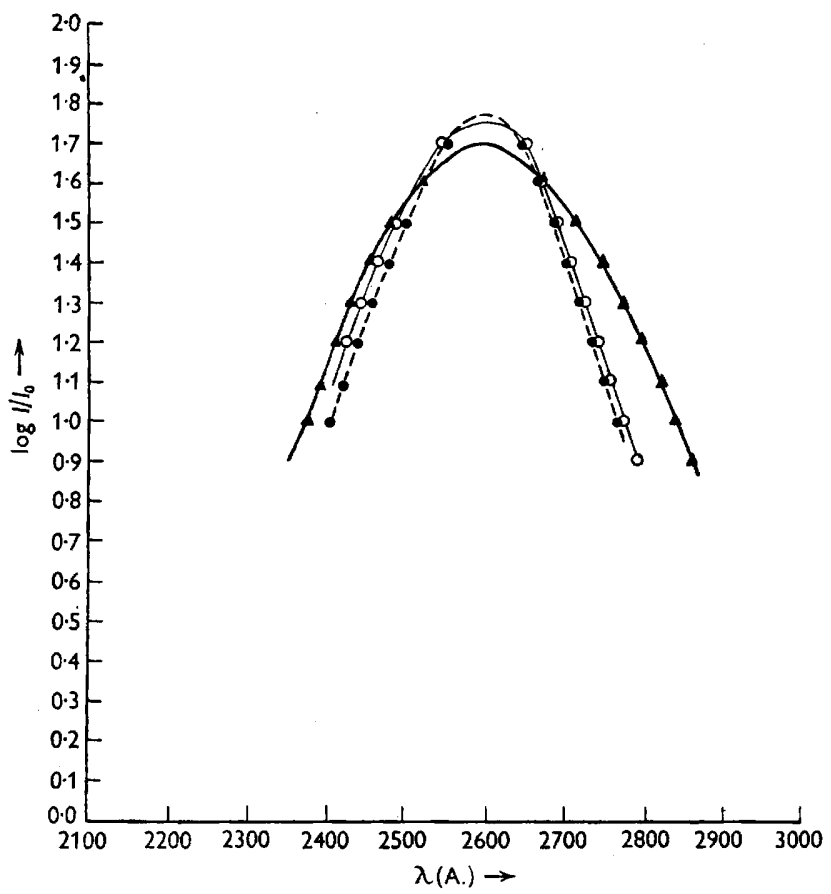

Fig. 1. Adsorption spectra of yeast ribonucleic acid $(0 . .-0)$ and the nucleic acids removed from Staph. albus $(\Lambda-\Lambda)$ and $\mathrm{Cl}$. welchii $(\mathrm{O}-\mathrm{O})$ by the action of lysozyme.

The preparations were hydrolysed by ribonuclease isolated from beef pancreas according to the method of Kunitz (1940).

The hydrolysis of the fractions produced by the enzyme at $\mathrm{pH} 6$ was followed according to the method of Davidson \& Waymouth (1944). Each tube of the experimental series contained $0.5 \mathrm{ml}$. of a solution of ribonuclease $(1 \mathrm{mg}$.) in distilled water (5 ml.), $0.2 \mathrm{M}$ acetate buffer $\mathrm{pH} 6.0(1.5 \mathrm{ml}$.) and $2.0 \mathrm{ml}$. of a $0.1 \%(\mathrm{w} / \mathrm{v})$ solution of the bacterial nucleic acid dissolved in $0.001 \mathrm{~m}$ sodium carbonate and adjusted to pH 6 with $0.001 \mathrm{~N}$ hydrochloric acid (Fig. 2).

In view of the specificity of ribonuclease and, in particular, of the fact that it does not attack deoxyribonucleic acid, this result, coupled with the analytical data, establishes the identity of the bacterial fractions with ribonucleic acid.

The preparations could be recoupled with cells rendered Gram-negative by extraction with $5 \%$ sodium cholate at $60^{\circ}$ (method of Henry \& Stacey, 1946). By this method the nucleic acid isolated from Staph. albus was 'replated' on to 
the Gram-negative cytoskeletons of $\mathrm{Cl}$. welchii (Pl. 1, figs. 6, 7) and that from Cl. welchii on to the Gram-negative cytoskeletons of yeast (Pl. 1, fig. 10).

In preliminary experiments the nucleic acid was converted to the magnesium salt by heating it with an aqueous suspension of magnesium carbonate according to the original method of Henry \& Stacey (1946). With the small samples of the bacterial nucleic acids available this procedure was not found satisfactory and alternative methods were investigated.

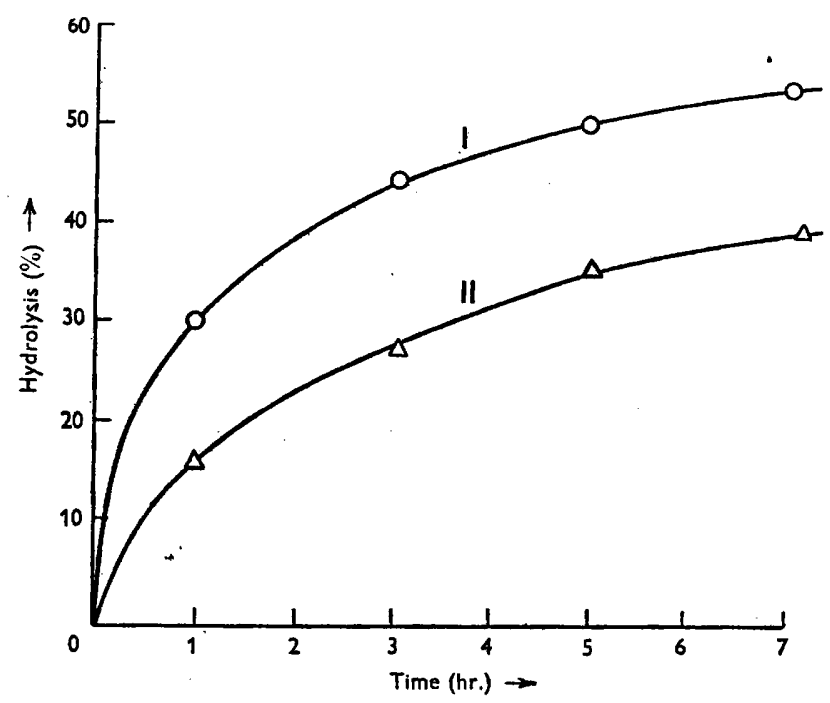

Fig. 2. Hydrolysis of the nucleic acids, removed from Staph. albus and Cl. welchii by lysozyme, with ribonuclease. $\triangle \longrightarrow \triangle$ nucleic acid from Staph. albus; $\bigcirc \longrightarrow O$ nucleic acid from $\mathrm{Cl}$. welchii.

Since a solution of authentic magnesium ribonucleate gave ionic reactions for magnesium, it appeared possible that a solution of sodium ribonucleate in the presence of magnesium ion would function as efficiently as magnesium ribonucleate in recoupling experiments. It was found that the presence of sodium ion $(0.5 \mathrm{M})$ had no inhibitory action on the combination of magnesium ribonucleate with the reduced cytoskeletons of $\mathrm{Cl}$. welchii. Furthermore, as a result of quantitative experiments in which the reduced $\mathrm{Cl}$. welchii cytoskeletons were added to serial dilutions of sodium ribonucleate in the presence of $0.012 \mathrm{M}$ magnesium sulphate to give opacities corresponding to no. $10 \mathrm{on}$ the standard barium sulphate opacity scale, it was established that as little as 0.1-0.2 mg. ribonucleic acid per ml. solution could thus be detected.

In contrast to the Gram-negative cytoskeletons obtained by sodium cholate extraction of Gram-positive organisms, killed cells rendered Gram-negative by the action of lysozyme and then reduced with formaldehyde could not be recombined with magnesium ribonucleate (Pl. 1, fig. 3). Since previous results had shown that lysozyme has no action on cells rendered Gram-negative with sodium cholate, cells rendered Gram-negative by lysozyme were subjected to extraction with the bile salt. 


\section{Extraction of cells rendered Gram-negative by the action of lysozyme with sodium cholate}

Gram-negative staphylococcus cells remaining after the action of lysozyme (p. 267) were suspended in $5 \%(\mathrm{w} / \mathrm{v})$ sodium cholate $\left(30 \mathrm{ml}\right.$.) at $60^{\circ}$. After 5 days the suspension was centrifuged and the clear supernatant (biuret positive) decanted. The residual cells were washed twice with distilled water and then suspended in $2 \%$ formol saline overnight. During this period the suspension agglutinated and separated as a fluocculent precipitate, although no disintegration of the cells occurred. After centrifuging, the cells were washed three times with distilled water and then resuspended in $4 \%$ magnesium ribonucleate. Stained smears prepared from the cells after 24 and $48 \mathrm{hr}$. at room temperature were, in each case, Gram-negative, showing that the cell bodies were not capable of recombining with ribonucleic acid.

Absolute ethanol (4 vols.) with $5 \mathrm{~N}$ acetic acid $(1 \mathrm{ml}$.) was added to the sodium cholate extract and the resulting precipitate collected at the centrifuge after $18 \mathrm{hr}$. The solid was suspended in distilled water $(20 \mathrm{ml}$.) and the suspension centrifuged after $20 \mathrm{~min}$. at room temperature. The insoluble material (II) was again extracted with distilled water $(10 \mathrm{ml}$.). The combined aqueous extracts (I) gave a positive Molisch reaction but a negative biuret. The insoluble fraction (II) gave a positive biuret and a negative Molisch reaction.

Addition of an equal volume of $0.25 \%(w / v)$ uranyl acetate in $2.5(\mathrm{w} / \mathrm{v})$ trichloroacetic acid resulted in the separation of a small precipitate which was collected after $6 \mathrm{hr}$. (supernatant, negative Molisch reaction). From this precipitate a fraction (2-3 mg.) was isolated, by the procedure previously outlined, which was identified as ribonucleic acid by the fact that it could be converted to the sodium salt and recombined with the Gram-negative cytoskeletons of $\mathrm{Cl}$. welchii in the presence of magnesium ion, to restore the initial Gramstaining properties.

Fraction II, after drying with ethanol and ether, yielded $10 \mathrm{mg}$. of a light brown powder which was insoluble in water and dilute acids, but which was soluble in dilute alkalis. It gave a positive biuret, ninhydrin and Sakaguchi reaction, but negative Millon, sulphur and Molisch tests, and appeared to be an acidic protein or polypeptide.

\section{DISCUSSION}

Of the Gram-positive micro-organisms submitted to the action of lysozyme, only yeast proved resistant to the action of the enzyme. It would, therefore, appear that fundamental differences exist between the structures of the Gram complex of yeast and of bacteria. The experimental results have shown that when suitable killed Gram-positive organisms are rendered Gram-negative by the action of lysozyme, small, but definite, amounts of reducing substances are liberated into solution. A similar increase in reducing groups occurs when solutions of the specific polysaccharides of the Gram-positive organisms are incubated with lysozyme. These carbohydrates appear to be located at or near 
the cell surface since they may be isolated by procedures which are not accompanied by changes in the Gram-staining reaction or by disintegration of the cells. Furthermore, cells which have been rendered Gram-negative by extraction with sodium cholate-a process accompanied by the removal of ribonucleic acid and polysaccharide from the cell surface-do not liberate reducing substances when incubated with lysozyme.

Since killed Gram-positive organisms are completely resistant to the action of trypsin (provided the latter is free from ribonuclease activity), while cells which have been rendered Gram-negative by enzyme action or by extraction with sodium cholate are lysed, it would appear that protein material is not normally exposed at. the cell surface. The outermost Gram-positive complex may, therefore, be considered to be composed of ribonucleic acid, specific carbohydrate and possibly lipid.

Concurrent with the partial hydrolysis of surface carbohydrate substances which occurs when lysozyme acts on killed cells, the Gram-staining reaction becomes negative and ribonucleic acid, the component of the complex responsible for the retention of the positive stain, is liberated into solution. This fact would suggest that, in the cell, ribonucleic acid and carbohydrate are in firm combination by means of linkages which are disrupted by the action of the enzyme. The isolation of a Gram-positive nucleoprotein (Henry et al. 1945) following a relatively short autolysis of $\mathrm{Cl}$. welchii, together with similar findings for pneumococcal autolysis (Thompson \& Dubos, 1938), shows conclusively that the ribonucleic acid of the Gram complex is also combined with cellular protein. Whether part of the latter together with ribonucleic acid is liberated from heat-killed organisms by the action of lysozyme remains to be determined. The evidence thus far obtained, however, leads to the conclusion that the major part of this protein is retained by the cell cytoskeleton.

Since all the killed Gram-positive organisms studied were, with the exception of Sacch. cerevisiae, susceptible to the action of lysozyme, while the specific polysaccharides of these organisms are known to be widely different in chemical structure, it is most probable that the action of lysozyme on the susceptible organisms is due to the ability of the enzyme to hydrolyse certain linkages common to these polysaccharides. Such linkages may well be those between carbohydrate and nucleic acid or between carbohydrate and protein. In support of this view is the finding that when bacterial cells or the specific polysaccharides from these cells are incubated with lysozyme the increase in free-reducing groups is relatively small. Meyer \& Hahnel (1946) have, however, stated that lysozyme in low concentration presumably catalyses the depolymerization of its substrate with little or no apparent increase in reducing groups.

In contrast to the present results, Epstein \& Chain (1940) were of the opinion that their polysaccharide substrate for lysozyme was contained within the bodies of the lysozyme-sensitive bacteria and they were unable to extract it with hypochlorite or formamide from the intact bacteria (M. lysodeikticus). However, as the authors were able to obtain complete lysis of suspensions of heat-killed $\boldsymbol{M}$. lysodeikticus by the combined action of lysozyme and trypsin, it is apparent, in view of the foregoing discussion, that the enzyme also brought 


\section{Action of lysozyme on Gram-positive bacteria}

about the hydrolysis of some surface carbohydrate material with consequent disintegration of the Gram complex. Support for the present argument is provided by the recent work of Feiner, Meyer \& Steinberg (1946) which has shown that the lysozyme substrate appears to be one of the antigens of $M$. lysodeikticus. It is, however, possible that two carbohydrates exist in $M$. lysodeikticus, both of which are susceptible to the action of lysozyme, the one forming part of the Gram complex and the other being contained in the somatic portion of the cell. The fortuitous occurrence of a carbohydrate substance in the cell bodies of $\boldsymbol{M}$. lysodeikticus capable of being more completely hydrolysed by lysozyme than the carbohydrate of the Gram complex may in part explain the difference in susceptibility towards the enzyme which exists between $\boldsymbol{M}$. lysodeikticus and most other organisms.

Thanks are due to Prof. M. Stacey for much helpful advice and criticism throughout this work, to Dr F. Smith for the adsorption spectra and to the University of Birmingham for the award of an I.C.I. Research Fellowship.

\section{REFERENCES}

Abraham, E. P. (1939). Some properties of lysozyme. Biochem. J. 33, 622.

Alderton, G., Ward, B. H. \& Fevold, H. L. (1945). Isolation of lysozyme from egg white. J. biol. Chem. 157, 43.

Alles, R. J. L. (1940). The estimation of phosphorus. Biochem. J. 34, 858.

Boasson, E. H. (1938). On the bacteriolysis by lysozyme. J. Immunol. 34, 281.

Caspersson, T., Hammarsten, E. \& Hammarsten, H. (1935). Interactions of proteins and nucleic acids. Trans. Faraday Soc. 31, 367.

Davidson, J. N. \& Waymourn, C. (1944). Tissue nucleic acids. II. The isolation and properties of liver nucleic acid. Biochem. $J .38,375$.

Dubos, R. J. \& MacLeod, C. M. (1938). The effect of a tissue enzyme on pneumococci. J. exp. Med. 67, 791.

Epstein, L. A. \& Chain, E. (1940). Some observations on the preparation and properties of the substrate of lysozyme. Brit. J. exp. Path. 21, 339.

Feiner, R. R., Meyer, K. \& Steinberg, A. (1946). Bacterial lysis by lysozyme. J. Bact. 52, 375.

Fleming, A. (1922). Remarkable bacteriolytic element found in tissues and secretions. Proc. Roy. Soc. 93, 306.

Fleming, A. \& Aluson, V. D. (1922). Bacteriolytic substance in secretions and tissues. Brit. J. exp. Path. 3, 250.

Friedberger, E. \& Hoder, F. (1932). Lysozyme and flocculation phenomenon of egg-white. Z. ImmunForsch. 74, 429.

Goldsworthy, N. E. \& Florey, H. (1930). Properties of mucus with special reference to its antibacterial function. Brit. J. exp. Path. 11, 192.

Hallauer, C. (1929). Ueber das Lysozyme. Zbl. Bakt. (1. Abt. Orig.), 114, 519.

HenRy, H. \& Stacey, M. (1946). Histochemistry of the Gram staining reaction for micro-organisms. Proc. Roy. Soc. B, 133, 391.

Henry, H., Stacey, M. \& TeEce, E. (1945). Nature of the Gram-positive complex in micro-organisms. Nature, Lond., 156, 720.

Jones, A. S., StaCey, M. \& Webb, M. (1948). The autolytic enzyme system of Grampositive micro-organisms. The proteolytic enzymes of staphylococci. Proc. Roy. Soc. B (in the Press).

Julianelie, L. A. \& Wieghard, C. W. (1935). The immunological specificity of the Staphylococcus. II. The chemical nature of the soluble specific substances. J. exp. Med. 62, 23. 
Kuemparskaya, N. N. (1939). Flocculation of bacteria by lysozymè. Z. Microbiol. Epidemiol. Immunitätsforsch (U.S.S.R.), 2, 124.

Kolmer, J. A. (1925). Infection, Immunity and Biologic Therapy, 3rd ed., p. 195. Philadelphia: Saunders.

Kunitz, M. (1940). Crystalline ribonuclease. J. gen. Physiol. 24, 15.

Mesrobeanu, L. \& Noeppel, O. (1938). Revue des travaux sur le lysozyme. Arch. roum. Path. exp. Microbiol. 11, 247.

MeXer, K. (1946). Currents in Biochemical Research, chap. 18, p. 277. New York: Interscience Publishers.

MeYer, K. \& HaHNEL, E. (1946). The estimation of lysozyme by a viscosimetric method. J. biol. Chem. 113, 723.

Meyer, K., Palmer, J. W., Thompson, R. \& Khorazo, D. (1936). On the mechanism of lysozyme action. J. biol. Chem. 113, 479 .

Peat, S., Bourne, E. J. \& Thrower, R. D. (1947). A new indicator for iodometric analysis. Nature, Lond., 159, 8.

Schaffer, P. A. \& Hartmann, A. F. (1920). The iodometric determination of copper and its use in sugar analysis. J. biol. Chem. 45, 365.

Spanier, P. \& Deribas, D. (1937). Les études sur la nature enzymatique nucléolytique du lysozyme. Rev. Microbiol. appliquée, 3, 61 .

SoмоGYI, M. (1937). A reagent for the copper-iodometric determination of very small amounts of sugar. J. biol. Chem. 117, 771 .

Thompson, R. (1940). Lysozyme and its relation to the antibacterial properties of various tissues and secretions. Arch. Path. Lab. Med. 30, 1096.

Thompson, R. H. S. \& Dubos, R. J. (1938). The isolation of nucleic acid and nucleoprotein fractions from pneumococci. J. biol. Chem. 125, 65 .

Thompson, R. \& Khorazo, D. (1935). Susceptibility to lysozyme of staphylococci. Proc. Soc. exp. Biol., N.Y. 33, 299.

\section{EXPLANATION OF PLATE}

The illustrations are prepared from direct contact prints taken from negatives on rapid process panchromatic plates. The bacterial cells, stained by Gram's method, are enlarged 1000 diameters.

Fig. 1. Heat-killed Gram-positive $\mathrm{Cl}$. welchii.

Fig. 2. Cl. welchii cells rendered Gram-negative by the action of lysozyme.

Fig. 3. The Gram-negative cells shown in Fig. 2 treated with $2 \%$ magnesium ribonucleate solution.

Fig. 4. Cl. weilchii cells rendered Gram-negative by extraction with $2 \%$ sodium cholate solution at $60^{\circ}$. (The variation in morphology apparent in this and the following photomicrographs of $\mathrm{Cl}$. welchii occurred when other peptones were used in the culture medium in place of Evans's Bacteriological peptone and will be more fully discussed in a subsequent communication.)

Fig. 5. The Gram-negative cells shown in Fig. 4 recoupled with $2 \%$ magnesium ribonucleate.

Figs. 6, 7. The Gram-negative cells shown in Fig. 4 recoupled with the magnesium salt of the nucleic acid removed from Staph. albus by the action of lysozyme.

Fig. 8. Cells of Saccharomyces cerevisiae after extraction with $2 \%$ sodium cholate solution at $60^{\circ}$.

Fig. 9. The Gram-negative cells shown in Fig. 8 rendered receptive with formaldehyde and recoupled with $2 \%$ magnesium ribonucleate.

Fig. 10. Cells shown in Fig. 8 rendered receptive with formaldehyde and recoupled with the magnesium salt of the nucleic acid removed from $\mathrm{Cl}$. welchii by the action of lysozyme. 
Journal of General Microbiology, Vol. 2, No. 3
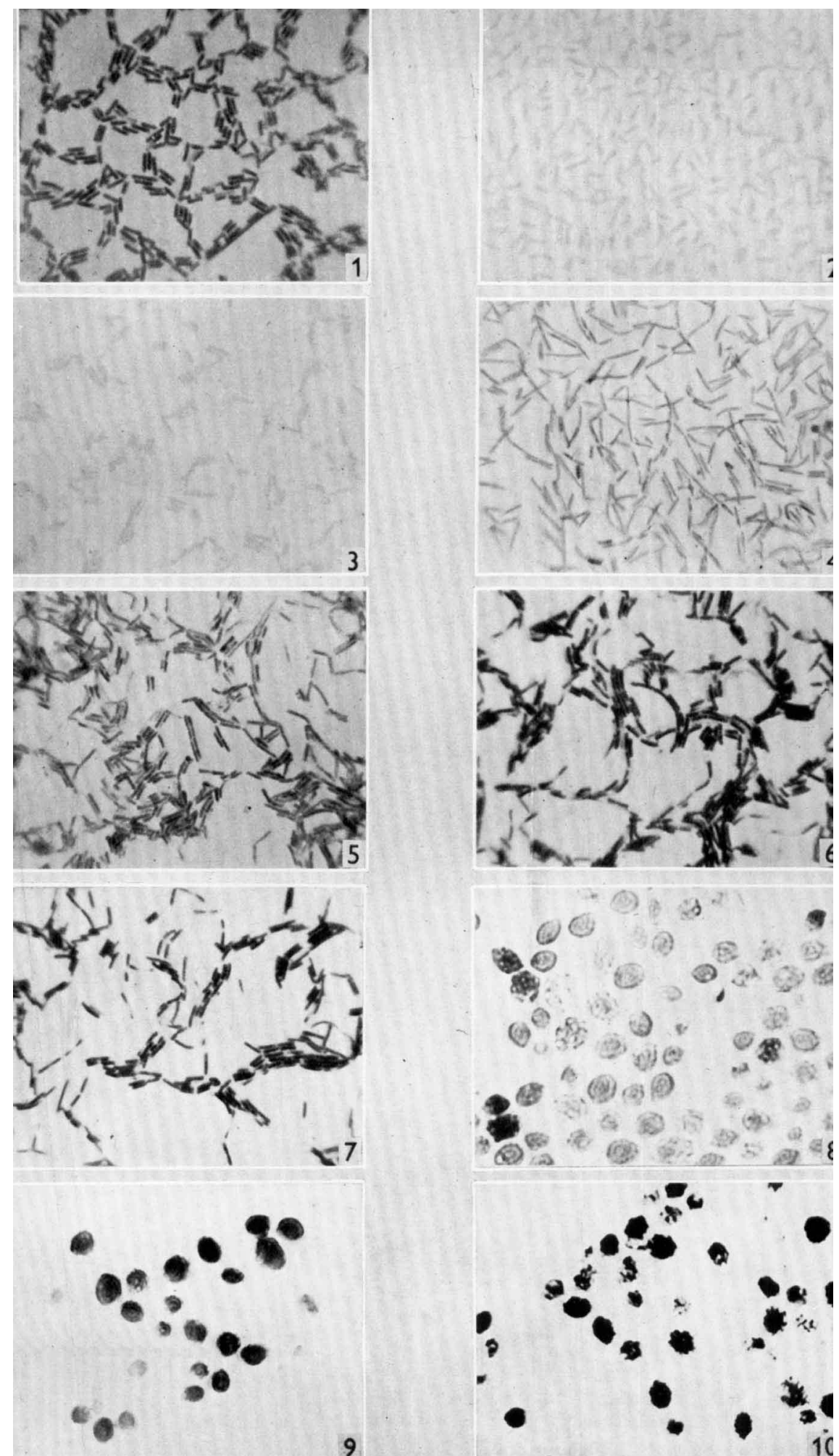

9

Figs. 1-10

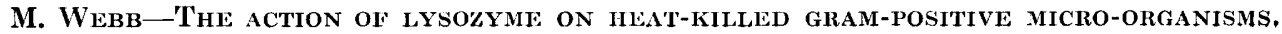
Plate 1 